\title{
简论农村公路工程建设的造价控制策略
}

刘安水

黔东南州公路处

DOI:10.32629/btr.v2i1.1774

[摘 要] 农村公路工程建设中,建设单位对提高工程质量、降低投资费用、按期或提前交付使用非常重视, 降低工程造价是建 设管理的重要目标之一, 而合理的工程造价是工程质量的经济保证, 因此对农村公路工程造价进行有效控制具有重要意义。基 于此,本文简述了农村公路工程造价控制的主要作用及其原则,对农村公路工程建设的造价控制策略进行了论述分析。

[关键词] 农村公路工程; 造价控制; 作用; 原则; 策略

农村公路工程建设质量关系到国民经济的长远利益, 关 系到人民的生命财产安全, 关系到 “三农” 问题, 关系到脱贫 攻坚, 所以造价人员必须参与项目建设的全过程, 才能做出 合理控制工程造价。由于影响公路工程造价的因素很多, 只 有在公路建设的各个阶段, 加强对工程造价进行主动控制, 才能杜绝建设资金浪费。以下就农村公路工程建设的造价控 制策略进行了探讨分析。

\section{1 农村公路工程造价控制的主要作用}

农村公路工程造价控制作用主要有：一是用于投资决 策; 二是用于筹集资金; 三是用于工程招投标; 四是用于工 程投资控制; 五是用于工程竣工决算。此外农村公路工程造 价控制还具有以下作用: (1) 合理使用人力、物力、财力和 自然资源, 缓解工程投资供需矛盾, 减少地方财政负担。(2) 控制工程建设总规模, 调节投资结构, 防止盲目建设, 重复建 设。(3) 加快工程建设速度, 提高投资的经济效益、社会效益 和环境效益, 加速公路工程建设投入产出的良性循环。

\section{2 农村公路工程造价控制的主要原则}

农村公路工程造价控制应遵循以下原则: 一是全面控制 原则。从农村公路工程的规划、设计、施工、交付使用阶段 等方面需要具备造价控制意识。二是目标管理原则, 即资金 支出必须依据预期的目标计划而行, 不得随意突破, 以最少 的投资创造最大的经济效益。三是技术与经济相结合的原则, 通过经济分析与技术比较、论证, 兼顾二者, 力求技术可行经 济合理。四是动态控制原则, 即对工程中的变化灵活处理, 分析变更产生的原因和必要性, 做好成本控制。五是责任与权 力相结合的原则, 即将成本控制落实到责任主体, 责任主体有 相应的权利和责任, 由于责任主体的原因造成资金浪费, 要承 担相应的经济责任, 有效控制农村公路全过程的工程造价。

\section{3 农村公路工程建设的造价控制策略分析}

3.1 农村公路工程建设投资决策阶段的造价控制策略分 析。(1) 投资决策阶段影响因素: 第一、工程建设规模、建 设标准等主要技术指标的采用。第二、路线走向方案、线型 布置是否合理; 第三、对重大的技术措施方案要有充足的分 析论证, 在平交、桥梁结构型式的采用上尤为重要; 第四、 工程沿线征地拆迁资料收集及调查是否全面。(2) 投资决策
阶段造价控制策略分析。第一、选择不同的道路等级, 工程 造价的差别可能是成倍的, 工程建设规模、建设标准等主要 技术指标是确定整个工程造价的决定因素, 所以采用何种道 路标准, 建设里程是非常重要的。第二、严格按基建程序办 事, 首先做好工程可行性研究, 是工程项目立项的基础, 委托 专业设计单位或咨询单位进行决策咨询, 实现决策的科学 化。选定几种路线走向方案, 进行综合比对, 选择线型最佳、 经济最合理的路线走向。第三、在我国投资决策过程可分为: 项目建议书阶段、工程可行性研究阶段和评审阶段。做好建 设项目的投资估算编制与审查工作, 不能走形式, 合理确定 建设项目总投资的计划控制额, 作为后续各阶段的造价控制 的基础。现行征地拆迁赔偿占工程总造价的比例越来越大, 调查收集齐全征地拆迁详细资料, 合理的拆迁赔偿估算在决 策阶段起到重要的作用。

3.2 农村公路工程建设的设计阶段造价控制策略分析。 (1) 合理编制施工图预算, 合理选择施工方案。设计阶段是控 制工程造价的关键环节, 设计人员在设计时要综合考虑技术 标准和经济性原则, 同时要与工程管理员多沟通, 在设计过 程对造价进行对比分析, 保证有效控制工程造价。为在符合 工程实际要求的基础上尽可能地降低工程造价, 尽量减少工 程材料费用, 就近利用周围材料或根据工程建设情况组织开 采, 或对老路进行扩建, 避免过度开挖, 减少耕地资源的占 用。对于施工图预算, 应首先注意工程量计算的准确性和套 用预算定额的正确性, 其次是注意其取费标准是否符合现有 的施工实际, 其中施工预算定额的控制应注意施工方案的合 理性及工程节约措施的切实可行、工程量的准确等。(2) 严 格设计变更管理, 加强造价动态控制。公路工程设计变更应 当符合国家有关公路工程强制性标准和技术规范的要求, 符 合公路工程质量和使用功能的要求, 符合环境保护的要求, 未经业主审查批准的设计变更不得实施。为加强工程造价的 动态控制, 要严格按照程序办理变更设计。每项工程变更设 计, 都要明确变更内容、数量、变更方案、变更金额, 分析对 比, 业主、驻地代表、监理人员层层把关。设计单位在编制 变更设计文件时, 应编制好变更设计预算报交通主管部门审 批, 防止利用变更设计抬高工程造价。(3) 推行限额设计, 全 
面控制工程造价。农村公路工程建设采用一阶段施工图设计, 建设单位应根据选定的技术标准、建设规模, 结合工程的地 形条件、资金来源, 确定投资估算, 然后委托设计单位进行施 工图设计。设计单位要在保证工程使用功能要求的前提下, 按各专业分配的限额优化设计, 不得突破投资估算。对设计 单位设计错误、漏项或扩大规模、提高标准而导致施工图预 算超过估算时, 建设单位 (业主) 要按相应比例扣减设计单位 的设计费用。

3.3 农村公路工程建设的招投标阶段造价控制策略分 析。招投标阶段是投标报价、标底编制直至工程竣工决算的 基础, 合理的招标文件是工程建设顺利进行的保障。因此首 先要根据相关规范, 确保招标文件内容清晰明确, 特别是材 料质量要求和工程质量等级要求, 为日后各项工作打下良好 基础。其次, 做好标底编制工作, 标底是投标报价的核心, 认 真核对各单项价格的成本, 招标控制价由建设单位人员与政 府审计部门人员认真审核后的价格作为最终政府控制价。价 格是影响施工过程的重要因素, 也是评标的主要依据, 因此, 标底编制坚持合理、公开、公正的原则。此外, 要改进评标 办法, 减少人为因素的影响, 选择评标办法既要考虑降低建 设成本, 又要能确保工程质量和进度, 评标结果要及时公布, 接受社会监督。为规范建设市场, 可引入市场竞争机制, 规 范施工队伍, 按招投标程序严格实行招标投标制度, 引入市 场竞争机制, 公平竞争, 优胜略汰。

3.4 农村公路工程建设的施工阶段造价控制策略分析。 (1) 合理计划工程建设使用资金。合理的工程建设资金使用 计划为工程造价合理控制提供了一个框架, 在实施过程中承 包单位须根据工程建设资金使用计划, 按月度、季度、年度 编制月报, 加大工程造价监管力度, 控制工程建设资金合理 运用, 专款专用, 严禁挪用。(2) 加强施工阶段价格控制。工 程造价管理贯穿工程建设的全过程, 而施工单位在施工阶段 的工程造价管理尤为重要。公路工程只有保证价格的合理性, 才能使投入发挥最大化的效益, 只有在造价人员全程参与工 程施工管理过程中, 才能做出较为合理经济的工程造价。农 村公路施工工艺简单, 机械化程度不高, 加上操作人员技术
水平的局限性, 导致施工过程不易控制, 所以在农村公路项 目管理时要经常参与施工现场, 调查好各施工现场的施工工 艺、材料运距及材料价格, 做好各项新增单价合理的同时, 为以后的农村公路工程建设造价提供依据。

3.5 农村公路工程建设的竣工阶段造价控制策略分析。 决算虽然是在工程建设完成以后, 但对整个农村公路工程建 设有一定的促进作用, 严谨的工程决算不但可以规范建设资 金的使用, 还能对前期施工工程质量起到能动作用。这个阶 段, 不仅审查人员必须具有较高的业务素质和丰富的审查经 验, 还需要具有良好的职业道德和较高的思想觉悟, 同时也 需要建设单位、监理人员、造价控制人员及施工单位等相关 方面人员的积极配合。竣工决算应以送审计部门审计后的决 算作为最终的决算价。通过工程决算的编制, 能够真实地反 映项目费用形成, 考核各项费用支出的必要性和合理性, 从 而达到规范管理, 堵塞漏洞的目的。

\section{4 结束语}

综上所述。农村经济发展的重要基础设施是农村公路, 近年来为彻底改变农村落后的交通现状, 实现全面建设小康 社会的宏伟目标, 多数农村已全面实施了农村公路改建工 程。而且有效控制农村公路工程建设的造价是利用有限资金 修好农村公路的重要手段, 因此必须加强对农村公路工程建 设的造价控制进行分析。

\section{[参考文献]}

[1]晋敏,张玉峰.农村公路建设全过程造价管理关键技 术研究 [J].建筑经济,2012,(07):34-36.

[2]王亚飞,王跃庭.农村公路建设项目管理关键技术研 究[J].科技视界, 2014,(10):312+329.

[3] 陈主元. 以设计阶段为重点有效控制农村公路工程造 价[J].黑龙江交通科技,2013,33(06):161。

[4] 陈琼芬.农村公路设计阶段工程造价控制策略探析 [J].中国房地产业,2016,(07):235-236.

[5]李雪斌.农村公路工程设计阶段造价控制措施探讨 [J].北方交通,2016,(07):162-164 